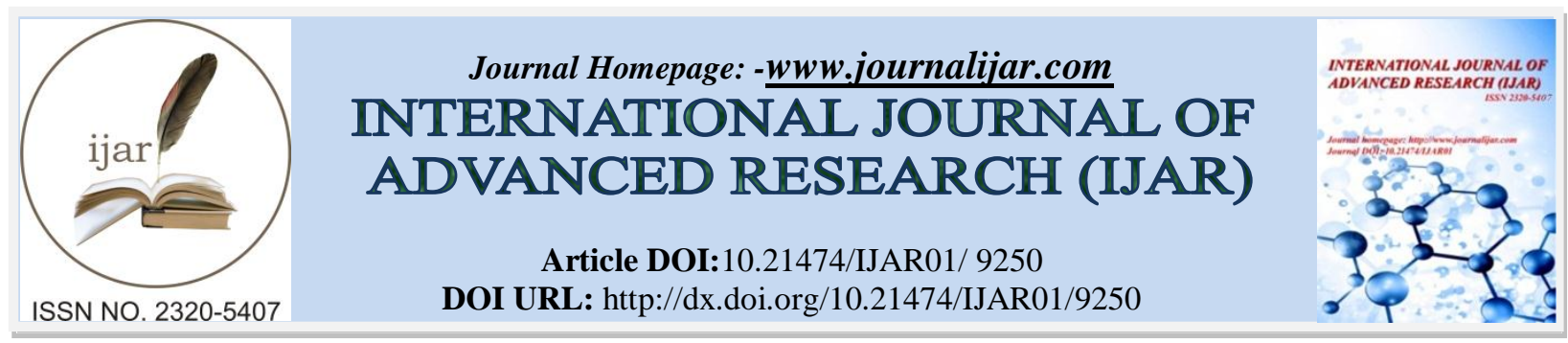

RESEARCH ARTICLE

\title{
HEAT INTEGRATION OF HYDROGEN PRODUCTION FROM GLYCEROL REFORMING.
}

\section{Tolulope O. Amlogu' ${ }^{1}$ And Omolola P. Dayo-Odukoya ${ }^{2}$.}

1. Department of Chemical Engineering, University of Lagos Akoka, Lagos State, Nigeria.

2. Department of Chemical and Biological Engineering, University of Sheffield Western Bank, S10 2TG, Sheffield, Great Britain.

\section{Manuscript Info}

Manuscript History

Received: 10 April 2019

Final Accepted: 12 May 2019

Published: June 2019

Key words:-

Glycerol reforming, Hydrogen production, Bio-diesel, Heat integration, Pinch analysis.

\section{Abstract}

Glycerol is a major by-product of bio-diesel, making up at least $10 \%$ of the biodiesel produced. In a world concerned about sustainability and recycling, this project aimed to find an alternative, cost-effective source of energy (hydrogen) from glycerol, a waste product of bio-diesel, via the reforming process. This study examined the use of the 'Pinch technology' as a technique in conserving energy in the glycerol reforming process for hydrogen production. The pinch analysis was carried out on two methods of reforming namely: Aqueous phase reforming (APR) and Steam reforming (SR). The results obtained showed that the unit production cost of $\mathrm{H}_{2}$ (in $\$ / \mathrm{kmol}$ ), before and after integration for APR are 31.68 and 31.56 consecutively and for SR- 48.7 and 52.99 consecutively. Energy recovered from APR and SR are 29, $820 \mathrm{~kW}(86 \%)$ and $37,400 \mathrm{~kW}(69 \%)$ respectively. These energy savings made, reduced the operating cost by $92 \%$ for APR and $75 \%$ for SR but an increased capital cost was incurred as a result of the additional heat exchangers that were required to achieve recovery. In this study, APR was found to be a more cost-effective and energy saving method (in both the non-integrated and integrated case), which makes it very ideal in our energy-dependent world, because it is carried out in liquid phase and at low or slightly elevated temperature.

Copy Right, IJAR, 2019,. All rights reserved.

\section{Introduction:-}

The demand for clean, renewable and sustainable energy has been on the rapid increase due to the depleting crude oil reserves and the negative impact unclean energy sources such as fossil-based fuel have on the atmosphere, the water cycle, and the general well-being of humans on planet earth ${ }^{1}$. These issues have led to various researches centered on discovering economically viable and environmentally friendly (clean) energy sources and as a result, new technologies requiring the use of renewable feed stock has been the focus of intense process developments within the past few decades ${ }^{2}$. The discovery of bio-fuel (fuel derived from biomass) was a major breakthrough in the search for clean energy. Currently, a few countries like the US are already making use of renewable feed stocks derived from biomass for production of diesel. According to the U.S Energy Information Administration (EIA) in 2016, diesel was a major part of the about $4.8 \%$ of biomass energy consumed in the U.S. Unfortunately this bio-fuel cannot compete favorably with fossil based fuel as a result of the economy of its production, that is, production $\operatorname{cost}^{3}$. According to the US Department of Energy, Alternative Fuel Data Centre, 2014, the cost of biodiesel is about 
$12 \%$ higher than the price of diesel. If biodiesel must compete with diesel effectively, alternative routes for reduction in production cost must be sought for.

Meanwhile, advancement in the production of biodiesel has led to the tremendous increase in supply of glycerol, being the major by-product of biodiesel. About $10 \%$ per unit mass of biodiesel produced is glycerol ${ }^{4}$. Although glycerol has been useful in other industries such as; food, beverages, body care, pharmaceutical etc., its rate of production far outweighs the demand for it in these industries. This has led to the oversupply and market flooding of glycerol, hence leading to drop in demand and market value (price) of glycerol. Over the years, it has been clearly observed that the amount of glycerol produced exceeds the actual consumption, and the mismatch is increasing further ${ }^{2}$. The U.S Department of Energy (DoE) estimates that if the United States were to produce enough biodiesel to displace only $2 \%$ of the current petroleum diesel usage, an additional 800 million pounds of glycerol would be produced per year.

Hydrogen $\left(\mathrm{H}_{2}\right)$ is a very attractive form of energy found useful in the chemical processing, transportation, petroleum, food and beverage industries amongst others ${ }^{5}$. Over the years, hydrogen has been produced by reforming hydrocarbon- natural gas (fossil fuel). This implies that a non-renewable fuel is being burnt in order to produce hydrogen. With so many concerns about 'human activities putting the planet in danger', this is not a recommended route for hydrogen production and can be greatly avoided by reforming glycerol, an oxygenated hydrocarbon which is from a renewable source ${ }^{6}$.

The Aqueous Phase Reforming (APR) is the only method in which the reforming is carried out in liquid phase at low or slightly elevated temperature. $\mathrm{H}_{2}$ can be generated without previous feed (glycerol and water) vaporization, therefore it requires less temperature and energy is conserved ${ }^{7}$. Steam reforming (SR) on the other hand is the oldest and most common method of reforming in industries ${ }^{8}$. It involves the splitting of hydrocarbons in the presence of steam at high temperature. It is described by the equation:
$\mathrm{C}_{3} \mathrm{H}_{8} \mathrm{O}_{3(\mathrm{~g})}+3 \mathrm{H}_{2} \mathrm{O}(\mathrm{g}) \leftrightarrow 7 \mathrm{H}_{2}+3 \mathrm{CO}_{2}$
--- Eq. 1

This method has high requirement for energy because it operates at very high temperature between 700 to $900^{\circ} \mathrm{C}^{9}$.

Heat integration also known as pinch technology is the systematic and general method for analysis, design and optimization of energy in a production system. It emphasizes on the efficient use of energy. Needs of opposite kinds are combined to enable savings. The field was birthed by the concept of heat recovery pinch guided by the principle of heat transfer with temperature difference as driving force ${ }^{10}$. It involves the merging of cold streams with hot streams, condensation with evaporation, identifying near optimal level of heat recovery and designing heat exchanger. Heat could be recovered and reused from one unit operation to another either by a direct process or an indirect process.

In view of all these, this research study was carried out using Aspen PLUS simulator to develop a cost effective method for hydrogen production from glycerol thereby improving the overall economy of the biodiesel production by;

1. developing and comparing 2 different methods of glycerol reforming that will be for cost-effective production of hydrogen and;

2. heat integration of the reforming processes developed, to minimize hydrogen production cost over a period of time.

\section{Experimental Section}

The Aspen PLUS simulator was used for the process development of the two reforming methods adopted: the Aqueous Phase Reforming (APR) and Steam Reforming (SR).

\section{Process Simulations \\ Pretreatment stage.}

The first process design was the pretreatment of the crude glycerol with $\mathrm{acid}^{7}$. Scheme 1 shows the flow sheet for the pretreatment process. Phosphoric acid $\left(\mathrm{H}_{3} \mathrm{PO}_{4}\right)-25 \% \mathrm{v} / \mathrm{v}$ was used. $\mathrm{H}_{3} \mathrm{PO}_{4}$ reacts with $\mathrm{KOH}$ in the crude glycerol to produce solid potassium salt as shown in the reaction in equation 2:

$\mathrm{KOH}+\mathrm{H}_{3} \mathrm{PO}_{4} \leftrightarrow \mathrm{KH}_{2} \mathrm{PO}_{4}+\mathrm{H}_{2} \mathrm{O} \quad$-----Eq. 2 
The solid potassium salt is separated by decantation. The stream flows into another reactor where hydrolysis of triolein takes place to produce fatty acid (oleic acid) and glycerol. The stream moves to the separator where oleic acid is separated from pure glycerol.

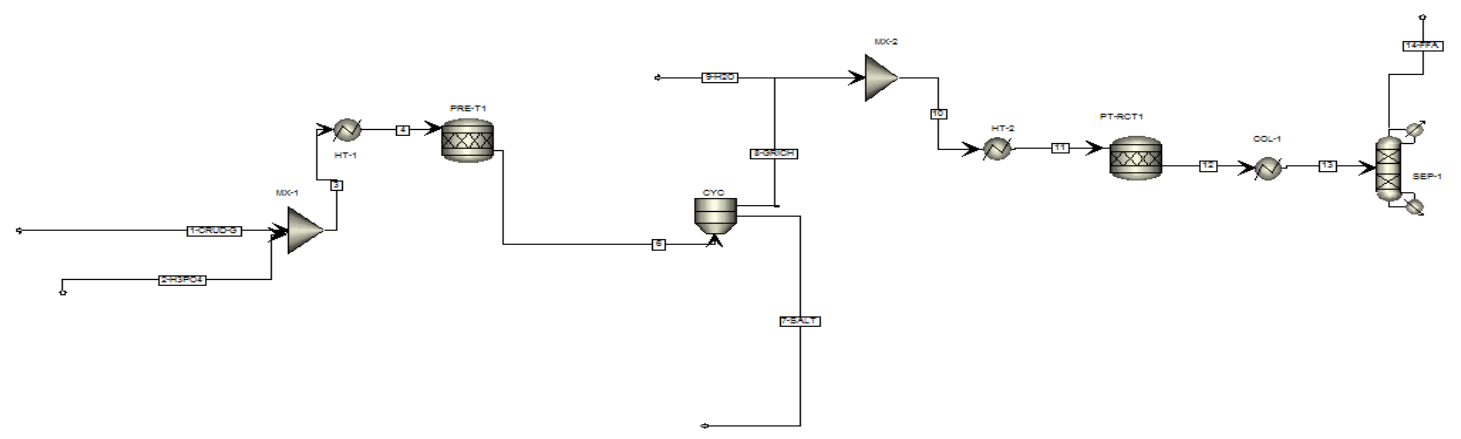

Scheme 1:-Process flowsheet for pretreatment.

\section{Aqueous phase reforming (APR) process simulation}

The property model Peng-Robinson was selected. The equilibrium reactor was assumed to model a heterogeneous system. Two reactions takes place in the reformer, one is the decomposition of glycerol and the other is the water gas shift reaction (WGS) which takes place in the ultra shift zone.

The unit operations, plant capacity and input conditions for this case that is, reforming of glycerol, were selected based on the research carried out by Davada et $\mathrm{al}^{5}$. The reactor temperature was set at $498 \mathrm{~K}\left(225^{\circ} \mathrm{C}\right)$ with a pressure of $38 \mathrm{bar}$. The process flow sheet is shown in scheme 2 .

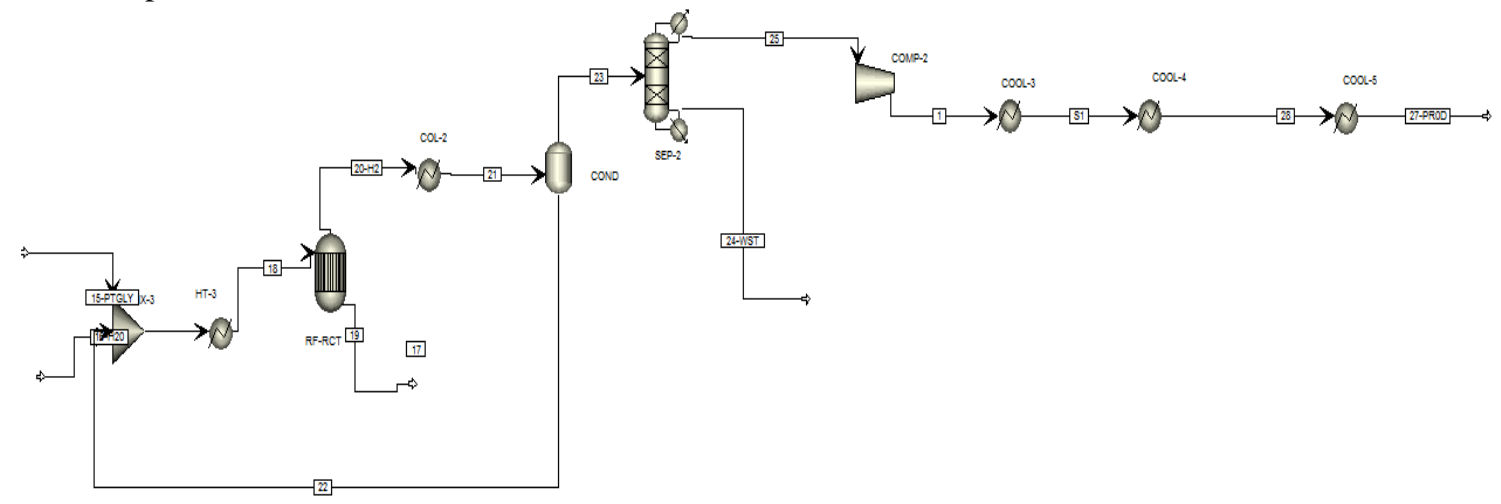

Scheme 2:-Process flow sheet for aqueous phase reforming.

\section{Steam Reforming (SR) Process Simulation}

The components for SR were selected, with property method GLYCOL for simulation. Process conditions for simulation were selected based on research carried out by Molburg et al ${ }^{12}$. The reactor temperature was set to $745^{\circ} \mathrm{C}$. The flow sheet is shown in scheme 3 below. 


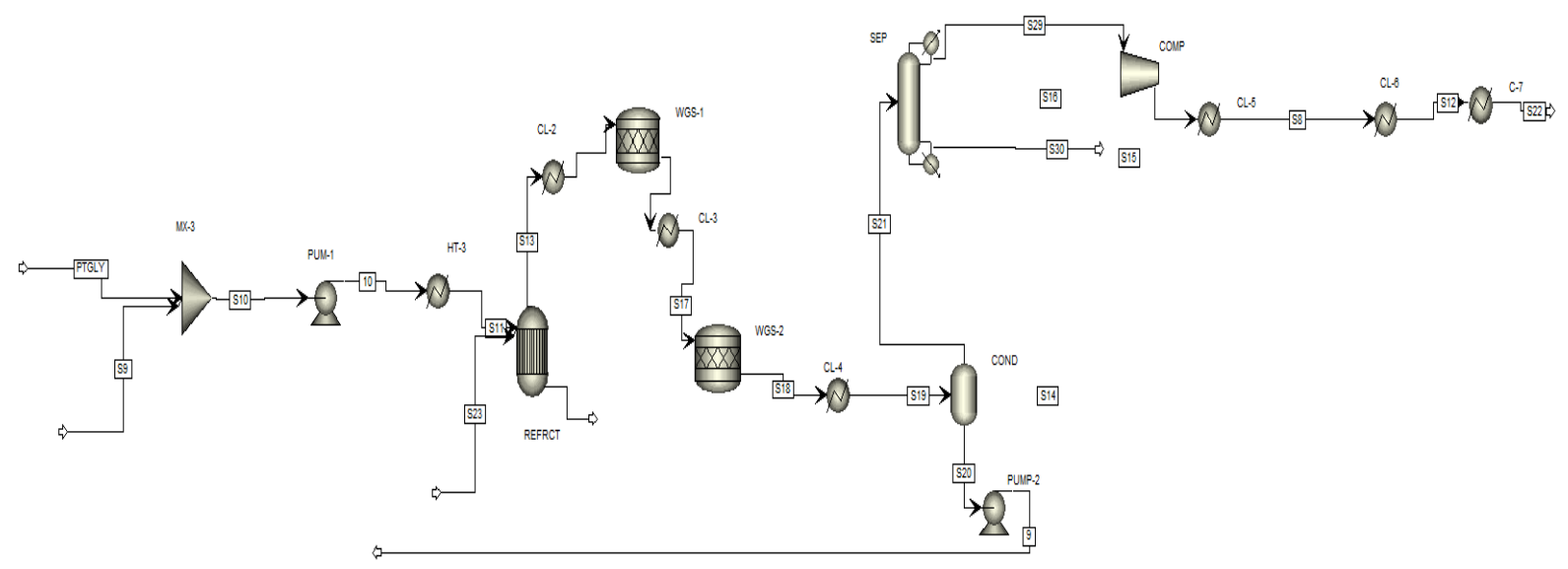

Scheme 3:-Process flow sheet for steam reforming.

\section{Heat Integration (Pinch Analysis)}

Heat integration was carried out with the following steps;

Obtained relevant data: Data such as heat load and temperature for all process streams and utilities were extracted from flow sheet of the simulated process design. The hot and cold steams were also identified. The necessary data for each process stream are the following: $\mathrm{T}_{\mathrm{s}}$ (source temperature, ${ }^{\circ} \mathrm{C}$ ); $\mathrm{T}_{\mathrm{t}}$ (target temperature, ${ }^{\circ} \mathrm{C}$ ) and; $\mathrm{CP}($ heat capacity flow rate $\left.\mathrm{KW} /{ }^{\circ} \mathrm{C}\right)$.

\section{Generated energy and utility targets:}

1. $\mathrm{DT}_{\min }$ is the minimum temperature difference between the hot composite curve and the cold composite curve at the pinch point (the point of closest approach between the two curves). It represents a tradeoff between the capital investment (which increases for smaller values of $\mathrm{DT}_{\min }$ ) and the operating cost (which reduces for smaller $\left.\mathrm{DT}_{\min }\right)$. The optimum $\mathrm{DT}_{\min }$ was obtained by plotting total cost targets against $\mathrm{DT}$ min.

2. Determine targets $\mathrm{Q}_{\mathrm{cmin}}$ (minimum external cooling utility required) and $\mathrm{Q}_{\mathrm{hmin}}$ (minimum external heating utilities required) by plotting composite curves. The heat load or enthalpy $(\Delta \mathrm{H})$ was computed using the formula below and then plotted against temperature.

$$
\Delta \mathrm{H}=\mathrm{CP}\left(\mathrm{T}-\mathrm{T}_{\mathrm{ref}}\right) \quad\left(\mathrm{T}_{\mathrm{ref}}-\text { the reference temperature }\right)
$$

$T$ represents $T_{s}$ or $T_{t}$ depending on what parameter is being calculated

Designed heat exchanger network: The heat exchanger network is designed and represented in a grid diagram by matching streams. The system is divided into 2 subsystem; 1 above pinch (higher temperature range) and the other below pinch (lower temperature range). The design starts at the pinch point and gradually moves away from the pinch making sure hot streams are utilized above pinch and cold stream utilized below pinch. The matching rules for pinch exchangers (those situated immediately above or below pinch) can be expressed mathematically by;

Above the pinch point, $\mathrm{CP}_{\mathrm{h}} \leq \mathrm{CP}_{\mathrm{c}}$; below the pinch point $\mathrm{CP}_{\mathrm{h}} \geq \mathrm{CP}_{\mathrm{c}}$ Where $\mathrm{CP}_{\mathrm{h}}$ represent heat capacity flow rate for hot stream and $\mathrm{CP}_{\mathrm{c}}$ represent heat capacity flow rate for cold stream If these rules are not satisfied then stream splitting would be required ${ }^{10,13}$.

\section{Costing}

Cost estimation of both reforming methods was carried out and its cost effectiveness determined. Aspen Economic analyser in combination with other method was use for cost estimation of the reforming processes.

\section{Factorial Method}

The fixed capital cost of the project is given as a function of the total purchase equipment cost by the formula ${ }^{14}$.

$$
\mathrm{C}_{\mathrm{f}}=\mathrm{f}_{\mathrm{L}} \times \mathrm{C}_{\mathrm{e}}
$$

Where: $C_{f}=$ fixed capital cost $C_{e}=$ the total delivered cost of all the major equipment items; $\mathrm{f}_{L}=$ the "Lang factor" (dependent on the process) $=3.63$ for fluids processing plant.

The cost factors that make up the Lang factors are broken down individually as seen in Table 1 
Table 1:-Typical factors for fixed capital cost estimation (extract from ${ }^{14}$ )

\begin{tabular}{|l|l|}
\hline Items & Process Type \\
\hline 1 Major equipment, total purchase cost & PCE \\
\hline $\mathrm{F}_{1}$ - Equipment erection & 0.45 \\
\hline $\mathrm{F}_{2}$-Piping & 0.45 \\
\hline $\mathrm{F}_{3}$-Instrumentation & 0.15 \\
\hline $\mathrm{F}_{4}$ Electrical & 0.10 \\
\hline $\mathrm{F}_{5}$-Buildings, process & 0.10 \\
\hline $\mathrm{F}_{6}$-Utilities & 0.45 \\
\hline $\mathrm{F}_{7}$-Storage & 0.20 \\
\hline $\mathrm{F}_{8}$-Site development & 0.05 \\
\hline $\mathrm{F}_{9}$-Ancillary Buildings & 0.20 \\
\hline PPE $\left(\sum\right.$ F) & 3.15 \\
\hline $\mathrm{F}_{10}$ Design and Engineering & 0.25 \\
\hline $\mathrm{F}_{11}$ Contractor's fee & 0.05 \\
\hline $\mathrm{F}_{12}$ Contingency & 0.10 \\
\hline$\left(\sum \mathrm{F}_{10-12}\right)$ & 1.40 \\
\hline $\mathrm{T}_{\mathrm{N}}$ Physical Plant & \\
\hline
\end{tabular}

Total Physical Plant cost $(\mathrm{PPC})=$ Installed Cost $\mathrm{x} \sum \mathrm{F}$

Fixed Capital $=$ PPC $\times F_{10-12}$

Heat Exchanger Cost

The cost of heat exchangers:

Capital cost $=a+b(A / N o \text {. of shells })^{c} \times$ No. Of shells

Where $A=$ Heat transfer area; $a, b$ and $c$ are constants with values 1000,800 and 0.8 respectively.

Variable Cost and Fixed Cost

The variable and fixed operating cost can calculated using information from Table 2 below.

Table 2:-Summary of production cost (extract from ${ }^{14}$ )

\begin{tabular}{|l|l|}
\hline Variable costs & Typical Values \\
\hline 1 Raw materials & From flow- sheets \\
\hline 2 Miscellaneous materials & $10 \%$ of maintenance \\
\hline 3 Utilities & From flow-sheet \\
\hline 4 Shipping and packaging & Usually negligible \\
\hline Sub-total A & \\
\hline Fixed cost & \\
\hline 5 Maintenance & $5-10 \%$ of fixed capital \\
\hline 6 Operating labour & From manning estimates \\
\hline 7 Laboratory cost & $20-23 \%$ of operating labour \\
\hline 8 Supervision & $20 \%$ of $(6)$ \\
\hline 9 Plants overhead & $50 \%$ of $(6)$ \\
\hline 10 Capital charges & $10 \%$ of fixed capital \\
\hline 11 Insurance & $1 \%$ of fixed capital \\
\hline 12 Local taxes & $2 \%$ of fixed capital \\
\hline 13 Royalties & $1 \%$ of fixed capital \\
\hline Sub-total B & \\
\hline Direct production cost A+B & \\
\hline 13 Sales expense & $20-30 \%$ of direct production cost \\
\hline 14 General overheads & \\
\hline 15 Research and development & \\
\hline Sub-total C & \\
\hline Annual production cost A+ B+ C= & \\
\hline
\end{tabular}




\section{Results And Discussion:-}

3.1 Pretreatment Stage

Table 3 shows the composition of glycerol, before and after pretreatment.

Table 3:-Composition of glycerol, before and after pretreatment

\begin{tabular}{|l|l|l|}
\hline Content & $\begin{array}{l}\text { Before Pretreatment } \\
\text { composition) }\end{array}$ & $\begin{array}{l}\text { After Pretreatment } \\
\text { composition })\end{array}$ \\
\hline Glycerol & 60 & 84 \\
\hline Water & 10 & 11.81 \\
\hline Triolein (Unreacted Triglyceride) & 15 & 0 \\
\hline KOH & 5 & 0.23 \\
\hline Methanol & 10 & 3.96 \\
\hline
\end{tabular}

\subsection{Aqueous Phase Reforming}

\section{Cost evaluation for non-integrated APR case}

In table 4, the cost of raw material required for the production of 2,000,000 $\mathrm{kmol} \mathrm{H}_{2}$ per annum which amounts to $\$ 22,272,920$ has been shown, as well as the utility cost and rates (approximately $\$ 812$ per hour) which is represented by table 5 and the summary of total production cost of APR shown in table 6 . These calculations show that it will cost approximately $\$ 32$ per kmol of $\mathrm{H}_{2}$.

Table 4:-Cost of raw materials required for production of 2million $\mathrm{kmol} \mathrm{H}_{2}$ per annum

\begin{tabular}{|l|l|l|l|l|}
\hline Name & Specification & Price $(\$)$ & Rate $/ \mathrm{yr}$ & Cost $(\$ / \mathrm{yr})$ \\
\hline Glycerol & Crude & $0.11023 / \mathrm{kg}$ & $8.5607 \times 10^{7} \mathrm{~kg}$ & $9.43652 \times 10^{6}$ \\
\hline Phosphoric acid & $99 \%$ & $25.448 / \mathrm{L}$ & $1.9 \times 10^{6} \mathrm{~L}$ & $1.20371 \times 10^{7}$ \\
\hline $\begin{array}{l}\text { Mains Water (process } \\
\text { water) }\end{array}$ & - & $0.00155 / \mathrm{L}^{*}$ & $9.62 \times 10^{9} \mathrm{~L}$ & $4.56 \times 10^{4}$ \\
\hline Catalyst $\left(\mathrm{Pt} / \mathrm{Al}_{2} \mathrm{O}_{3}\right)$ & $5 \mathrm{wt} \%$ & $10,324 / \mathrm{kg}$ & $73 \mathrm{~kg}$ & $7.537 \times 10^{5}$ \\
\hline \multicolumn{2}{|l}{ Total } & & & ${\mathbf{2 . 2 2 7 2 9 2} \times \mathbf{1 0}^{7}}$ \\
\hline
\end{tabular}

*Cost of water is given as seen in the industrial water pricing for OCED countries.

Table 5:-Utility rates and cost

\begin{tabular}{|l|l|l|l|}
\hline Name & Fluid & Rate $(\mathrm{Btu} / \mathrm{hr})$ & Cost $(\$ / \mathrm{hr})$ \\
\hline Electricity & & $746.374 \mathrm{~kW}$ & 57.843985 \\
\hline AP-UTIL-U-3 & Steam & $505,717.5$ & -1.330037 \\
\hline AP-UTIL-U-4 & Steam & $904,565.2$ & -1.800085 \\
\hline AP-UTIL-U-UCLN33 & Propane & $99,788,940$ & 288.390037 \\
\hline AP-UTIL-U-CLN5 & Propane & $798,417.1$ & 2.307425 \\
\hline AP-UTIL-U-HT1 & Steam & $506,624.3$ & 1.013249 \\
\hline AP-UTIL-U-HT2 & Steam & $6,580,769$ & 24.283038 \\
\hline AP-UTIL-U-HTN1 & Steam & $114,402,900$ & 422.146701 \\
\hline AP-UTIL-U-VL & Propane & $6,463,417$ & 18.679275 \\
\hline Total & & & $\mathbf{8 1 1 . 5 3 3 5 8 8}$ \\
\hline
\end{tabular}

The remaining generation of high energy is considered as service in ASPEN hence the negative sign.

Table 6:-Total Production Cost for APR

\begin{tabular}{|l|l|l|}
\hline \multicolumn{2}{|l|}{} & Cost $(\$)$ \\
\hline Fixed Capital & & $29,800,645.00$ \\
\hline \multirow{2}{*}{ Fixed Operating Cost } & Taxes & $447,009.68$ \\
\cline { 2 - 3 } & Insurance & $447,009.68$ \\
\cline { 2 - 3 } & Maintenance & $2,980,064.50$ \\
\hline Variable Operating Cost & Utilities & $7,109,034.21$ \\
\cline { 2 - 3 } & Raw Materials & $22,272,920.00$ \\
\cline { 2 - 3 } & Miscellaneous Operating & $298,006.45$ \\
\hline
\end{tabular}




\begin{tabular}{|l|l|l|}
\hline & Material & \\
\hline Total & & $\mathbf{6 3 , 3 5 4 , 6 8 9 . 5 2}$ \\
\hline
\end{tabular}

Therefore the total manufacturing cost of 2 million $\mathrm{kmol} \mathrm{H}_{2}$ is $\$ 63,354,689.52$ per annum

\section{Pinch Analysis for APR}

$$
\begin{gathered}
\text { Production cost of } \mathrm{H}_{2} / \mathrm{kmol}=\frac{63,354,689.53}{2,000,000} \\
=\$ 31.68 \mathrm{kmol}^{-1}
\end{gathered}
$$

Stream data required for pinch analysis such as inlet and outlet temperature, enthalpy were extracted from the flow sheet. The data is shown in the table 7.

Table 7:-Stream Data for APR

\begin{tabular}{|l|l|l|l|l|l|l|}
\hline Name & Type & $\mathrm{T}_{\mathrm{s}}\left({ }^{\circ} \mathrm{C}\right)$ & $\mathrm{T}_{\mathrm{t}}\left({ }^{\circ} \mathrm{C}\right)$ & $\mathrm{CP}(\mathrm{kJ} / \mathrm{C} . \mathrm{h})$ & Enthalpy(kW) & Segment \\
\hline 1 & Hot & 329.8372 & 25 & $153,862.6771$ & 2,199 & Hot \\
\hline 2 & Hot & 270 & 25 & - & 1,894 & Hot \\
\hline 3 & Cold & 57 & 270 & - & 1,929 & Cold \\
\hline 4 & Cold & 47.2 & 255 & - & $3.353 \times 10^{4}$ & Cold \\
\hline 5 & Hot & 255 & 100 & - & $2.925 \times 10^{4}$ & None \\
\hline
\end{tabular}

\section{Determining Energy and Utility Targets}

The composite curve is plotted with stream data in order to determine the energy targets. From the plot in figure 1, it is observed that the optimum $\mathrm{DT}_{\min }$ (minimum temperature that will give us the maximum energy recovery) is $6^{\circ} \mathrm{C}$.

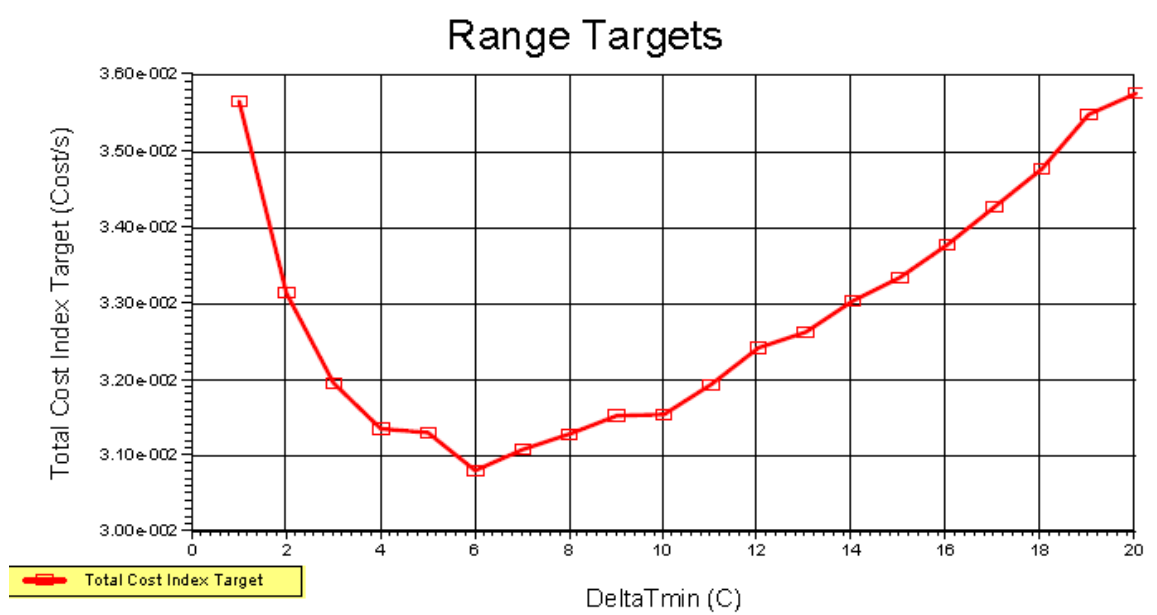

Figure 1:-Optimum DT ${ }_{\min }$ plot for APR

The optimum $\mathrm{DT}_{\min }$ is used in plotting the composite curve as seen in figure 2 . The amount of energy recoverable from the process as shown by the region of overlap on the composite curve is $29,820 \mathrm{~kW}$. The energy targets $\mathrm{QC}_{\min }$ and $\mathrm{QH}_{\min }$ are seen in the plot as 3,519kW and 5,787 kW respectively. The pinch temperature was obtained from the curves as $225.4^{\circ} \mathrm{C}$. The summary is given in table 8 . 


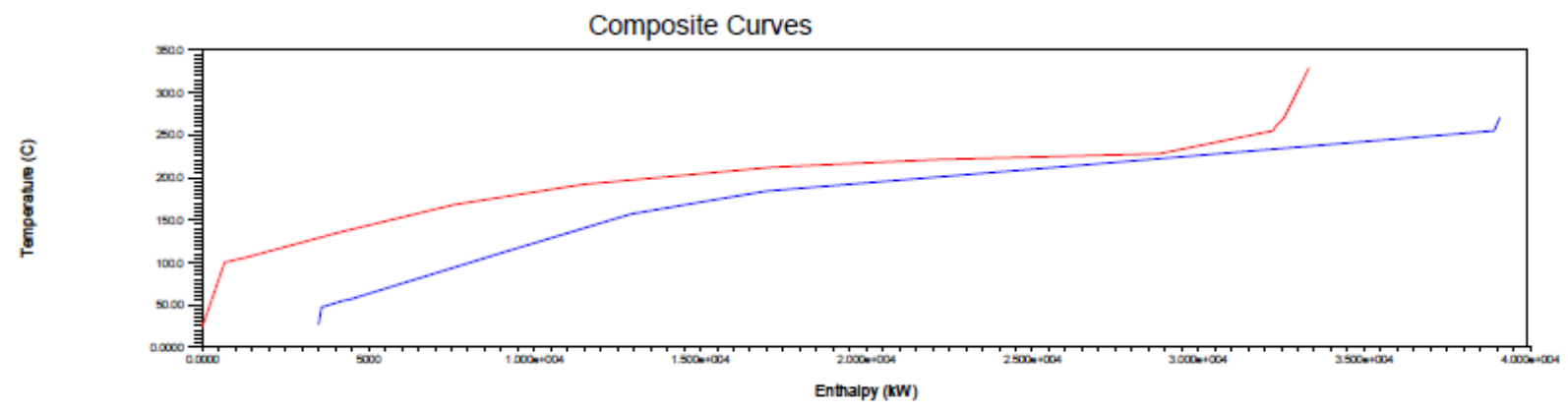

Figure 2:-Composite curve for APR (*Indicators: Red - hot; Blue - cold)

Table 8:-Heat Recovery Summary

\begin{tabular}{|l|l|l|}
\hline & Heating & Cooling \\
\hline Non-integrated APR Simulation Energy Requirement (kW) & 35,607 & 33,339 \\
\hline Energy Targets (kW) & 5,787 & 3,519 \\
\hline Savings (kW) & $2.982 \times 10^{4}$ & $2.982 \times 10^{4}$ \\
\hline Savings (\%) & 83.7 & 89.4 \\
\hline
\end{tabular}

\section{Heat Exchanger Network Design for APR}

Capital Cost of heat exchanger network was calculated using data extracted from Aspen PLUS. After pinch analysis was carried out, the grid diagram was designed for integrated APR case. The number of heat exchangers increased to 15 which consist of 3 coolers, 4 heaters and 8 stream to stream heat exchangers. As a result of these, the heat transfer area of the heat exchangers increased to $6081 \mathrm{~m}^{2}$ with 54 shells as shown in table 9.

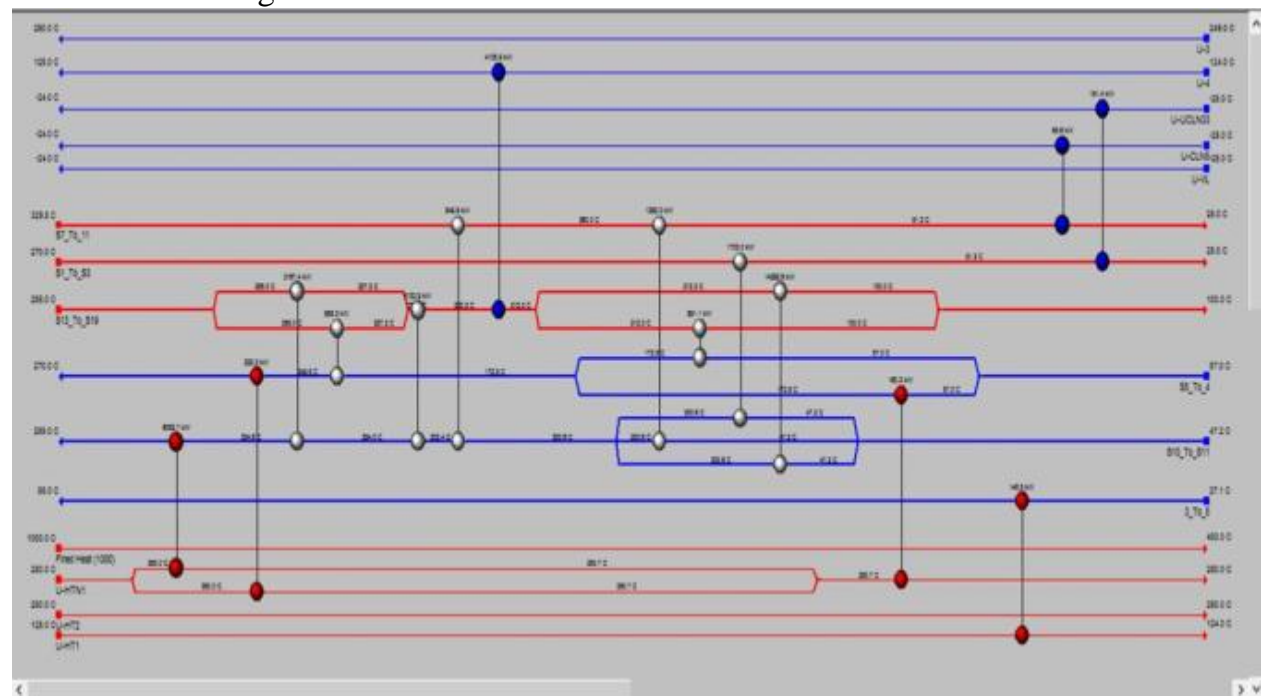

Figure 3:-Heat exchange network for integrated APR case.

The blue circles linked with vertical lines are cooler while the red ones represent heaters, the grey ones represent stream to stream heat exchangers.

\section{Cost Evaluation for APR after Integration}

The total utility cost (energy cost), as shown in Table 9, required for plant operation per year is $\$ 7,109,034.21$. A saving of $92 \%$ was achieved (from operating costs) through heat integration which amounts to $\$ 6,563,297.14$. 
Table 9:-Summary of Energy Cost

\begin{tabular}{|l|l|l|l|}
\hline & $\begin{array}{l}\text { Non-integrated APR } \\
\text { Case }\end{array}$ & Integrated APR Case & Deficit/Surplus \\
\hline No. of units & 8 & 15 & \\
\hline No of Shells & 15 & 54 & \\
\hline Area $\left(\mathrm{m}^{2}\right)$ & 3,432 & 6,081 & $6,327,854.91(198 \%)$ \\
\hline $\begin{array}{l}\text { Heat Exchanger Capital } \\
\text { Cost }(\$)\end{array}$ & $6,471,000$ & $12,798,854.91$ & $6,563,297.12$ \\
\hline Operating Cost $(\$ / y r)$ & $7,109,034.21$ & $545,737.09$ & \\
\hline Operating Cost Savings $(\%)$ & 0 & 92 & \\
\hline Total Production Cost $\$$ ) & $63,354,689.52$ & $63,119,247.31$ & \\
\hline $\begin{array}{l}\text { Unit Production Cost of } \mathrm{H}_{2} \\
\left(\$ / \mathrm{kmol}^{-1}\right)\end{array}$ & 31.69 & 31.56 & \\
\hline
\end{tabular}

The capital cost for the integrated APR case is higher, due to the increased heat transfer area, but a total of $92 \%$ was save from operating cost (utilities). Therefore the unit cost of production of $\mathrm{H}_{2}$ after heat integration is:

$$
\begin{gathered}
\text { Production cost of } \mathrm{H}_{2} / \mathrm{kmol}=\frac{63,119,247.31}{2,000,000} \\
=\$ 31.56 \mathrm{kmol}^{-1}
\end{gathered}
$$

\section{Steam Reforming}

The cost evaluation for the non-integrated SR case was carried out just as it was done for the APR case above using data extracted from Aspen Economic Analyzer. Table 10 shows the breakdown of production cost for SR.

\begin{tabular}{|c|c|c|}
\hline & & Cost $(\$)$ \\
\hline \multicolumn{2}{|l|}{ Fixed Capital } & $34,100,057.11$ \\
\hline \multirow[t]{3}{*}{ Fixed Operating Cost } & Taxes & $511,500.86$ \\
\hline & Insurance & $511,500.86$ \\
\hline & Maintenance & $3,410,005.71$ \\
\hline \multirow[t]{3}{*}{ Variable Operating Cost } & Utilities & $36,306,520.80$ \\
\hline & Raw Materials & $22,272,920.00$ \\
\hline & $\begin{array}{l}\text { Miscellaneous Operating } \\
\text { Material }\end{array}$ & $341,000.57$ \\
\hline Total & & $97, \mathbf{4 5 3 , 5 0 5 . 9 1}$ \\
\hline
\end{tabular}

Table 10:-Total Production Cost for SR

The total manufacturing cost of 2 million $\mathrm{kmol} \mathrm{H}_{2}$ is $\$ 97,453,505.91$ per annum. Hence:

$$
\begin{gathered}
\text { Production cost of } \mathrm{H}_{2} / \mathrm{kmol}=\frac{97,453,505.91}{2,000,000} \\
=\$ 48.73 \mathrm{kmol}^{-1}
\end{gathered}
$$

\section{Pinch Analysis for SR}

Stream data shown in Table 11, such as inlet and outlet temperature $\left({ }^{\circ} \mathrm{C}\right)$ and enthalpy $(\mathrm{kW})$ were extracted from the flow sheet, the heat capacity flow rate (kJ/C.h) was calculated using Aspen Energy Analyzer.

Table 11:-Process Stream Data for SR

\begin{tabular}{|l|l|l|l|l|l|l|}
\hline Stream & Type & $\mathrm{Ts}\left({ }^{\circ} \mathrm{C}\right)$ & $\mathrm{Tt}\left({ }^{\circ} \mathrm{C}\right)$ & $\mathrm{CP}(\mathrm{kJ} / \mathrm{C} . \mathrm{h})$ & Enthalpy $(\mathrm{kW})$ & Segment \\
\hline 1 & HOT & 745.437 & 350 & $118,683.1$ & $13,036.58$ & None \\
\hline 2 & HOT & 270 & 25 & - & $1,900.241$ & Hot \\
\hline 3 & COLD & 47.42801 & 745.437 & - & $52,607.23$ & Cold \\
\hline 4 & HOT & 204.445 & 100 & - & $22,508.51$ & Hot \\
\hline 5 & COLD & 56.97533 & 270 & - & $1,933.836$ & Cold \\
\hline 6 & HOT & 427 & 204.445 & - & $14,357.95$ & Hot \\
\hline 7 & HOT & 327.6606 & 25 & - & 1871 & Hot \\
\hline 8 & COLD & 27.12742 & 55 & $19,179.05$ & 148.4916 & None \\
\hline
\end{tabular}


Pinch analysis was carried out in other to obtain the possible energy saving for the SR process.

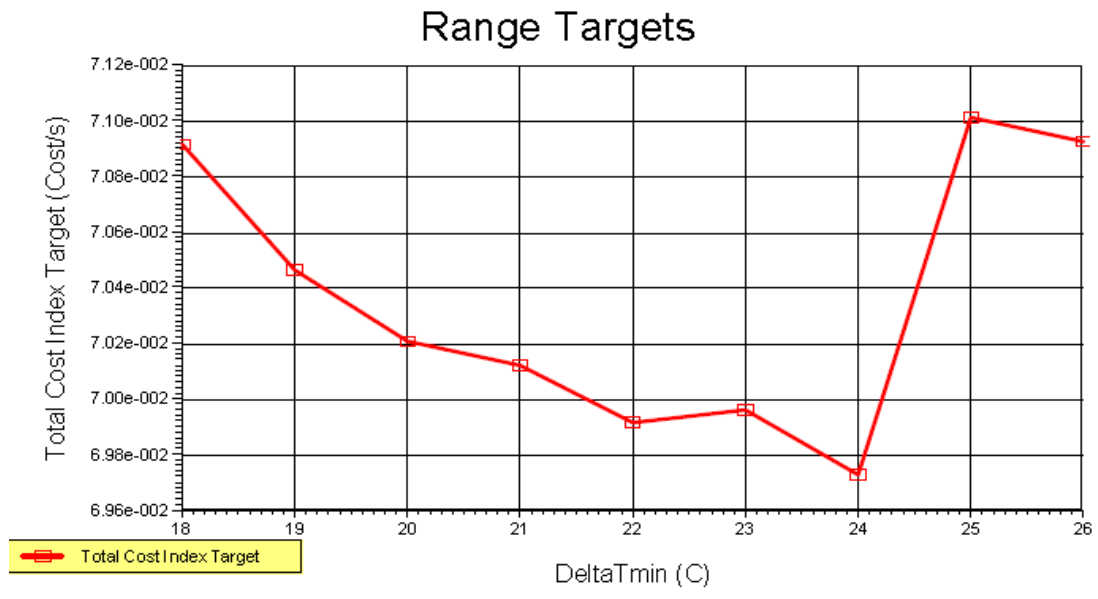

Figure 4:-Optimum $\mathrm{DT}_{\min }$ for $\mathrm{SR}$

The composite curve is plotted with stream data in order to determine the energy targets. The optimum $\mathrm{DT}_{\min }$ is first determined to be $24^{\circ} \mathrm{C}$. Figure 5 shows the composite curve.

The region of overlap on the composite curve is $37,400 \mathrm{~kW}$, with a pinch temperature of $217.2^{\circ} \mathrm{C}$.

The summary of heat recovery is shown in Table 12 below

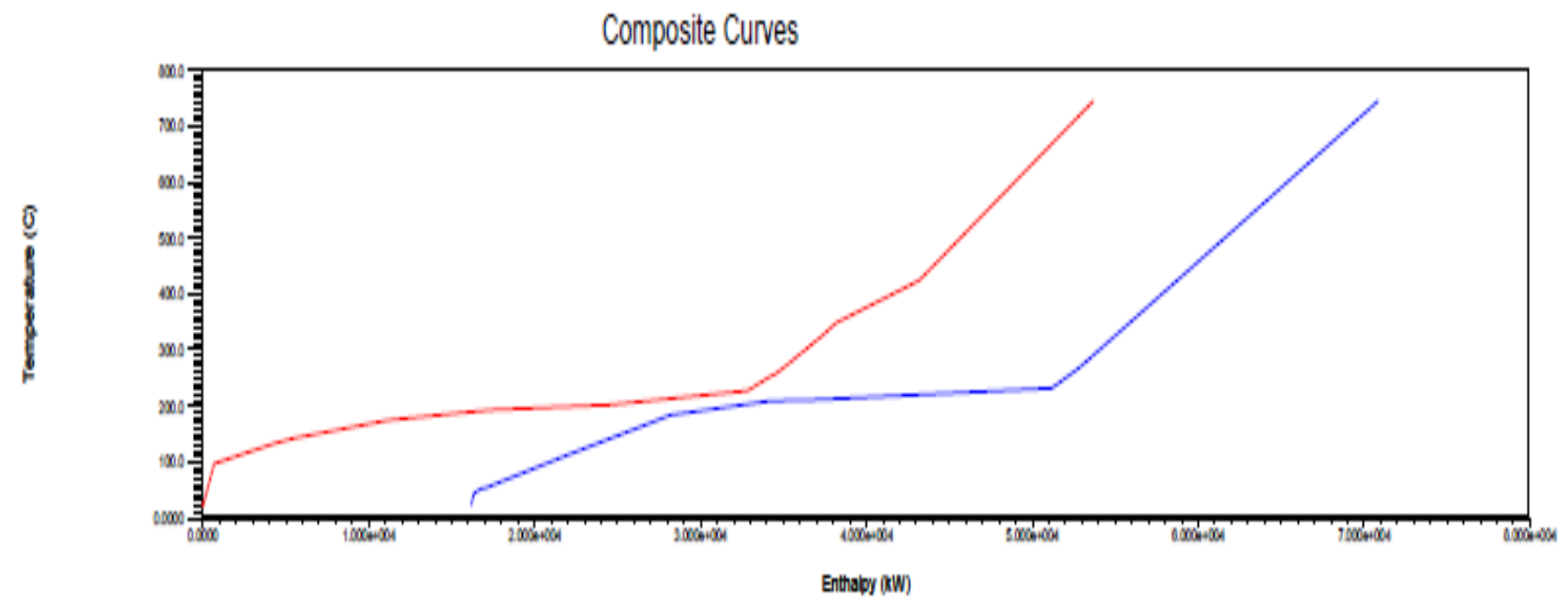

Figure 5:-Composite curve for SR

Table 12:-Heat recovery summary for SR

\begin{tabular}{|l|l|l|}
\hline & Heating & Cooling \\
\hline Non-Integrated SR Simulation Energy Requirement (kW) & 54,680 & 53,670 \\
\hline Energy Targets (kW) & 17,240 & 16,240 \\
\hline Savings (kW) & 37,400 & 37,400 \\
\hline Savings (\%) & 68.4 & 69.7 \\
\hline
\end{tabular}




\section{Heat Exchanger Network Design for SR}

After pinch analysis was carried out, the grid diagram was designed for the integrated SR case. The number of heat exchangers increased to 20 . As a result of these, the heat transfer area of the heat exchangers increased to $6,903 \mathrm{~m}^{2}$ with 61 shells.

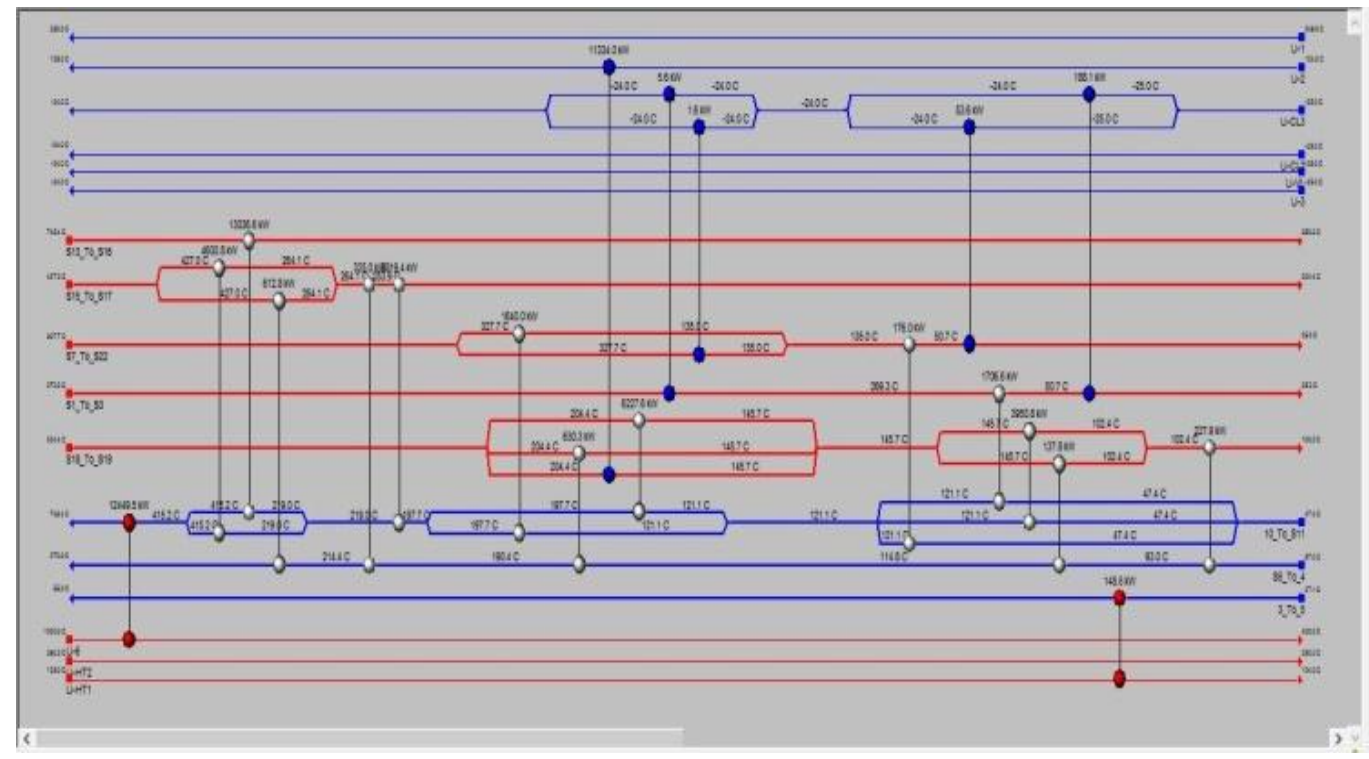

Figure 6:-Heat exchange network integrated SR case

The total utility cost (energy cost), as shown in Table 13 , required for plant operation per year is $\$ 36,306,520.80$. A saving of $75.2 \%$ of operating cost was achieved through heat integration. Capital Cost of heat exchanger network was calculated using data extracted from Aspen PLUS.

Table 13:-Production cost for both SR cases.

\begin{tabular}{|l|l|l|l|}
\hline & $\begin{array}{l}\text { Non-integrated SR } \\
\text { Case }\end{array}$ & Integrated SR Case & Deficit/Surplus \\
\hline No. of units & 9 & 20 & \\
\hline No. of Shells & 11 & 61 & \\
\hline Area $\left(\mathrm{m}^{2}\right)$ & 788 & 6903 & $35,848,287(612 \%)$ \\
\hline Heat Exchanger Capital Cost $(\$)$ & $7,002,253$ & $42,850,540$ & $27,303,839.49$ \\
\hline Operating Cost $(\$ / y r)$ & $36,306,520.80$ & $9,002,681.31$ & \\
\hline Operating Cost Savings $(\%)$ & 0 & 75.2 & \\
\hline Total Production Cost $(\$)$ & $97,453,505.91$ & $105,997,953.42$ & \\
\hline Unit Production Cost $\left(\$ \mathrm{kmol}^{-1}\right)$ & 48.7 & 52.99 & \\
\hline
\end{tabular}

The capital cost for the integrated SR case is higher due to the increased heat transfer area, but a total of $75.2 \%$ was saved from operating cost (utilities). Therefore the cost of production of $\mathrm{H}_{2}$ after heat integration is

$$
\begin{gathered}
\text { Production cost of } \mathrm{H}_{2} / \mathrm{kmol}=\frac{105,997,953.42}{2,000,000} \\
=\$ 52.99 \mathrm{kmol}^{-1}
\end{gathered}
$$

\section{Discussion:-}

This comparative study between the heat integration of APR and SR was carried out in order to determine the cost effective method. The plant requires 85.6 million $\mathrm{kg}$ of glycerol to run per year in order to produce 2 million $\mathrm{kmol}_{2}$.

Heat integration was carried out in order to maximize energy, by recovering energy from stream to stream matching. The total recoverable amount of energy was determined from the composite curve plot, the hot and cold composite are placed together on a single temperature-enthalpy plot. The hot and cold composite curves represent the sum of all heat sources and all heat sinks respectively within a process. To do this appropriately, the optimum $\mathrm{DT}_{\min }$ was first determined. The optimum $\mathrm{DT}_{\min }$ will give us a balance between capital cost and operating cost. It represents a 
tradeoff between the capital investment (which increases for smaller values of $\mathrm{DT}_{\min }$ ) and the energy/operating cost (which reduces for smaller $\mathrm{DT}_{\min }$ ). $\mathrm{DT}_{\min }$ was determined for $\mathrm{APR}$ and $\mathrm{SR}$ as $6^{\circ} \mathrm{C}$ and $24^{\circ} \mathrm{C}$ respectively. Having done this, the composite curve is plotted. The plot showed that a total of $29,820 \mathrm{~kW}(86 \%)$ was recovered from the APR non-integrated case, with appropriate stream matching with the aid of the grand composite curve.

Operating cost for the APR of which utilities is a $\$ 7.11$ million was reduced by $92 \%$ to $\$ 0.55$ million. From the new network design, the integrated case had a total of 15 heat exchangers consisting of 3 coolers, 4 heaters and 8 stream to stream heat exchangers, as a result the new heat transfer area increased to $6081 \mathrm{~m}^{2}$.

The cost evaluation carried out gave an overall $0.37 \%$ savings on total cost of production with $\$ 31.68 \mathrm{kmol}^{-1}$ and $\$ 31.56 \mathrm{kmol}^{-1}$ as the unit cost of $\mathrm{H}_{2}$ for the non-integrated case and integrated case respectively. The mere $0.37 \%$ saving is insignificant and discouraging when compared to the $198 \%$ increase in the capital cost of heat exchangers implementation, but a more critical analysis showed that the savings made from the operating cost(utilities) would make up for the increased capital cost over a short period of time.

A similar analysis was carried out on Steam reforming (SR) using the same procedure as in APR above. The composite curve revealed that a total of $37,400 \mathrm{~kW}(69 \%)$ was recovered with heat integration. The operating cost was reduced by $75.2 \%$ from $\$ 36.31$ million to about $\$ 9$ million. The new network design has a total of 20 heat exchangers including coolers, heaters and stream to stream heat exchangers leading to a transfer area of $6903 \mathrm{~m}^{2}$. An increase in production cost of about $9 \%$ with unit production cost of $\$ 52.99 \mathrm{kmol}^{-1}$ of $\mathrm{H}_{2}$ for integrated case and $\$ 48.7 \mathrm{kmol}^{-1}$ for the non-integrated case SR case.

A massive increase was seen in the capital cost for heat exchangers due to the implementation of the new stream to stream heat exchanger for the maximization of energy in form of utilities.

From results obtained, it is safe to say that heat integration does not necessarily bring about an upfront reduction in production cost but rather production cost is saved over a short period of time through savings from utilities. It is wiser to save operating cost while investing in capital cost because capital cost is fixed and would not need review in the nearest future but operating cost is variable and could change based on different factors such as; government policies, availability etc.

\section{Conclusion:-}

The previously wasted glycerol is now found useful for energy production, in the form of hydrogen. Revenue generated from this would improve the biodiesel economy greatly and above all gradually sweep out environmental pollution from fossils fuels as the use of biodiesel increases. This study has proven the fact that aqueous phase reforming (APR) is a more cost-effective and energy saving method (in both the non-integrated and integrated case). With steam reforming there is a high demand for energy and this comes in as a disadvantage to the energy dependent world.

The break even analysis showed that the additional capital cost incurred due to the additional heat exchangers would be gained back from the savings made from the operating cost over the break even period. For the APR, it will take 12 months ( 1 year) for the surplus (savings) from operating cost to pay for the deficit from heat exchangers capital cost. For the SR the break even period is 16 months.

\section{Acknowlegement:-}

I appreciate Dr. Usman Lawal of University of Lagos, Akoka for his support all through and to the completion of this work. 


\section{References:-}

1. Riddell A. Ronson, S. Counts, G. and Kurt,S. "Towards Sustainable Energy: The Current Fossil Fuel Problem and the Prospects of Geothermal and Nuclear Power," 2015. [Online]. Available: http://web.stanford.edu/class/e297c/trade_environment/energy/hfossil.html. [Accessed 17 July 2016]

2. Avasthi K. S, Reddy R. N, Patel S. (2013). Challenges in the production of hydrogen from glycerol-a biodiesel byproduct via steam reforming process. Procedia Engineering, 51: 423 - 429

3. Energy Information Administration, Monthly Energy Review, March 2016, Table 10.3, http://www.eia.gov/totalenergy/data/monthly/pdf/sec10_7.pdf

4. Silvey L. G. (2011). Hydrogen and Syngas Production from Biodiesel Derived Crude Glycerol.

5. Davda R. R, Shabaker J. W, Huber G. W, Cortright R. D, Dumesic J. A. (2005). A review of catalytic issues and process conditions for renewable hydrogen and alkanes by aqueous-phase of oxygenated hydrocarbons over supported metal catalysts. Applied catalysis B:environmental, 56: 171- 176.

6. Sabri, F. (2013). Catalysts for hydrogen production by the auto-thermal reforming of glycerol, M.Sc Thesis, University of Regina, Saskatchewan.

7. El Doukkali, M. Iriondo, A. Cambra, J. Gandarias, I. Jalowiecki-Duhamel L. Dumeignil, F. and Arias P.L. (2014). Deactivation study of the Pt and /or Ni-based y- $\mathrm{Al}_{2} \mathrm{O}_{3}$ catalysts used in the aqueous phase reforming of glycerol for $\mathrm{H} 2$ production. Applied Catalysis, 472: 80-91.

8. Roussière, T. L. (2013). Catalytic reforming of methane in the Presence of CO 2 and H $2 \mathrm{O}$ at high pressure. Ph.D. Dissertation, Karlsruhe Institute of Technology, October 2013.

9. Stelmachowski, M. (2011). Utilization of glycerol, a by-product of the transestrification process of vegetable oils: a review. Ecological Chemistry and Engineering, 18 (1).

10. Gundersen, T. (2000). A Process Integration Premier, International Energy Agency. Sintef Energy Research.

11. Nanda, M. R, Yuan, Z. Qin, W. Poirier, M. A and Chunbao, X. (2014). Purification of Crude Glycerol using Acidification: Effects of Acid Types and Product Characterization. Austin J Chem Eng, 1(1): 1004.

12. Molburg, J. C, Doctor, R. D. (2003). Hydrogen from steam methane reforming Argonne NationalLaboratory, $20^{\text {th }}$ Annual International Pittsburgh Coal Conference, 7-19.

13. CANMET Energy Technology Centre- Varennes. (2003). Pinch Analysis: For efficient use of energy water and hydrogen. Natural Resource Canada.

14. Sinnott, R. K. (2005). Chemical Engineering Design. Coulson and Richardson's Chemical Engineering Series. Elsvier Butterworth-Heinemann, 6(4): 243-258. 